University of Colorado Law School

Colorado Law Scholarly Commons

Getting a Handle on Hazardous Waste Control

(Summer Conference, June 9-10)

6-9-1986

\title{
Regulation of Wastes from the Metals Mining Industry: The Shape of Things to Come
}

Lawrence J. MacDonnell

Follow this and additional works at: https://scholar.law.colorado.edu/getting-handle-on-hazardous-wastecontrol

Part of the Administrative Law Commons, Environmental Engineering Commons, Environmental Health and Protection Commons, Environmental Law Commons, Environmental Policy Commons, Jurisdiction Commons, Legislation Commons, Litigation Commons, Natural Resource Economics Commons, Natural Resources and Conservation Commons, Natural Resources Law Commons, Natural Resources Management and Policy Commons, Oil, Gas, and Energy Commons, Oil, Gas, and Mineral Law Commons, Science and Technology Law Commons, and the State and Local Government Law Commons

\section{Citation Information}

MacDonnell, Lawrence J., "Regulation of Wastes from the Metals Mining Industry: The Shape of Things to Come" (1986). Getting a Handle on Hazardous Waste Control (Summer Conference, June 9-10).

https://scholar.law.colorado.edu/getting-handle-on-hazardous-waste-control/10 


\section{William A. Wise Law Library
Colorado \\ UNIVERSITY OF COLORADO BOULDER

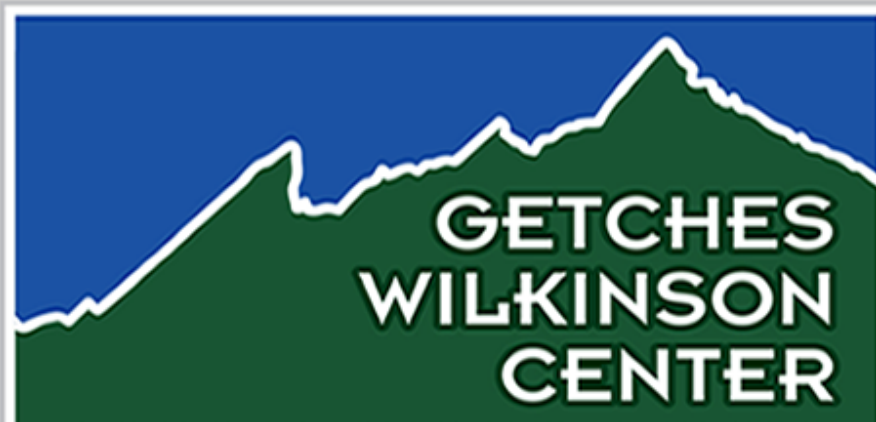 \\ FOR NATURAL RESOURCES, ENERGY, AND THE ENVIRONMENT \\ Getches-Wilkinson Center Collection}

Lawrence J. MacDonnell, Regulation of Wastes from the Metals Mining Industry: The Shape of Things to Come, in GetTing a Handle on HAZARDous WASTE CONTROL (Natural Res. Law Ctr., Univ. of Colo. Sch. of Law 1986).

Reproduced with permission of the Getches-Wilkinson Center for Natural Resources, Energy, and the Environment (formerly the Natural Resources Law Center) at the University of Colorado Law School. 


\title{
REGULATION OF WASTES FROM THE METALS MINING INDUSTRY: THE SHAPE OF THINGS TO COME
}

\author{
Lawrence J. MacDonnell \\ Director \\ Natural Resources Law Center \\ University of Colorado School of Law \\ Boulder, Colorado 80309-0401
}

Presentation Given at Conference on the Changing World Metals Industries

Sponsored by Columbia University and the U.S. Bureau of Mines May $12-15,1986$ 


\section{INTRODUCTION}

Once viewed as a valuable legacy of Colorado's mining origins, a number of old mining sites in the state are now the subject of multimilion dollar lawsuits filed by the state of Colorado against past and present owners. For example, the state alleges that mining activities dating back to 1878 at the Idarado Mine in southwestern Colorado near the town of Telluride have contaminated ground water, harmed aquatic life in adjacent surface streams, and degraded air quality. Wastes from the Eagle Mine, located eight miles from Vail, Colorado, are thought to have significantly reduced the aquatic populations in the Eagle River at that location. The Yak Tunnel/California Gulch site near Leadville, Colorado is said to be the source of acid mine drainage into the Arkansas River, local ground water contamination, and contaminated particulates in the air.1

Suits have been brought to recover for damages to natural resources caused by release of hazardous substances from the sites and others, and to recover all costs of remedial action needed to clean them up. Such actions were authorized by the Comprehensive Environmental Response, Compensation and Liability Act (CERCLA), often referred to as "Superfund," passed by Congress in 1980 in reaction to disclosure of the severe damage caused by chemical wastes dumped into Love Canal in upstate New York years before. Concern that other abandoned sites might be causing similar damage prompted Congress to establish procedures for identifying and cleaning up such sites. Several states, 
including Colorado, are using this law to target old mining and processing sites.

Congress has also been concerned with the problem of newly generated hazardous wastes. With the Resource Conservation and Recovery Act (RCRA), passed in 1976, Congress established a comprehensive regulatory scheme for such wastes. However, because of uncertainty about how to treat mining wastes, Congress asked the Environmental Protection Agency (EPA) to undertake a special look at the wastes generated during the mining, milling, and processing phases. EPA submitted its report to Congress on mining and milling wastes on December 31, 1985. EPA's decision regarding regulation of these wastes must be made by June 30 , 1986 .

The general issue of mine waste management has important economic consequences for the mining industry. This paper focuses on the metals mining sector. By way of background, the general subject of wastes from mining is addressed first. Most of this material is drawn from the recent EPA report to Congress. Next, the two key federal laws--RCRA and CERCLA--are examined, with special reference to their effect on mining. Finally, the issues of mine waste regulation and natural resource damage suits are considered in more detail.

There is little question that government involvement in the management of mining wastes is here. However, the shape and extent of that involvement still has not been finally determined. Hopefully, government action will be proportionate to the 
real need for such involvement and will address the special problems posed by such involvement.

\section{THE NATURE OF THE PROBLEM}

The mining, milling, and processing of metallic ores produce enormous quantities of waste materials. The EPA report to Congress estimates that the mining and beneficiation of metallic ores between 1910 and 1981 produced nearly 41 billion metric tons of tailings and mine wastes. 2 In 1982 alone, 438 metal mines generated an estimated 926 million metric tons of waste. 3

The actual metallic content of the ore being mined is typically very small. Copper, for example, is mined at a grade of about . 6 of one percent. Thus, as the Bureau of Mines has shown, 420 units of material must be handled for every one unit of marketable material that is produced. Just to gain access to the ore deposit, the overburden or other surrounding rock must be removed. The beneficiation process generates tailings which must be contained in settling ponds. Tailings and other low grade ore may be subjected to leaching techniques involving the use of acid to extract the metallic content. Once this process is complete, these materials are waste. EPA estimates that the waste rock created in gaining access to the ore deposits constitutes about 44 percent of the mining wastes generated annually; tailings after beneficiation account for about 33 percent of the annual mining wastes; and the waste materials left after leaching activities constitute the remainder. 4 The copper segment 
accounts for more than half of all mine wastes generated by metallic mining and beneficiation. See Table 1.

The quantities of waste involved are impressive. Of greater direct interest, however, is whether these wastes present a problem for human health and the environment such that some kind of governmental control over their management is warranted. These wastes are already subject to an array of federal and state regulatory controls. When Congress enacted the Resource Conservation and Recovery Act in 1976, it was sufficiently unsure of the need to directly regulate mining wastes that it ordered EPA to study the problem. EPA finally produced a report on mining and milling wastes in December 1985.

In analyzing the potential danger to human health and the environment from mining wastes, the report begins by noting that:

Mining wastes may contain constituents, such as heavy metals, other toxic elements, radionuclides, cyanide compounds, and asbestos, that may be dangerous to human health and the environment. In addition, some mine wastes are corrosive (acidic) and others have a high potential for forming acid. 5

Based on standards established for determining hazardous waste characteristics, EPA estimates that 61 million metric tons of mining waste generated annually are hazardous. Although this is less than five percent of all mining wastes generated annually, it is roughly the same amount as all other hazardous waste from all other industrial sources produced each year. 6 Most of these mining wastes classified as hazardous come from copper dump leach operations ( 82 percent). Also identified as 


\section{Waste Generated By Metallic Mining}

MINING

INDUSTRY

MINE

LEACHING

SEgment

WASTE TAILINGS

WASTE

TOTAL

(MILLIONS OF METRIC TONS PER YEAR)

\begin{tabular}{|c|c|c|c|c|}
\hline COPPER & 124 & 178 & $20 \cap$ (DUMP) & 502 \\
\hline GOLD & 39 & 24 & 11 (HEAP) & 74 \\
\hline IRON & 102 & 75 & - & 177 \\
\hline LEAD & 2 & 9 & - & 11 \\
\hline MOLyBDENUM & 24 & 6 & - & 30 \\
\hline SILVER & 20 & 6 & $<1$ (HEAP) & 26 \\
\hline URANI UM & 73 & NA & - & 73 \\
\hline ZINC & 1 & 6 & - & 7 \\
\hline OTHER METALS & 23 & 3 & - & 26 \\
\hline TOTAL & 408 & 307 & 211 & 925 \\
\hline
\end{tabular}

Source: Epa Mine Waste Peeport, Table ES-1, 
potentially hazardous are 23 million tons per year of cyanidecontaining wastes, 95 million tons per year of wastes with high acid formation potential, and 182 million tons per year of copper leach dump wastes with potential for releasing toxic metals and acidic liquids. 7 See Table 2 .

Still unanswered is the question of the actual risk to human health and the environment posed by these hazardous wastes. - The report points out that hazardous materials may migrate off the mining site as a result of releases from surface impoundments or from seepage into underlying ground water. 8 It cites examples of such occurrences based on its own studies and the studies of others.9 As part of its risk assessment, EPA is now studying release rates, exposure pathways, and possible effects on human health and the environment.

Based on its findings, EPA is to decide whether to regulate mining wastes under the hazardous waste provisions of RCRA by June 30, 1986. The significance of this decision to the U.S. metal mining industry is evidenced by the estimates of the cost of such regulation. EPA developed cost estimates based on two different assumptions regarding the kinds of waste that would be considered hazardous and four different regulatory "scenarios."10 As shown in Table 3, the larger waste group causes 80 percent of all mine facilities to be regulated, involving 40 percent of all mine wastes. Dependent on the assumptions employed, the additional annual cost of such regulation ranged from a low of $\$ 7$ million to a high of $\$ 854$ million.ll within 


\section{Estimated "Hazardous" Metallic Mining Wastes}

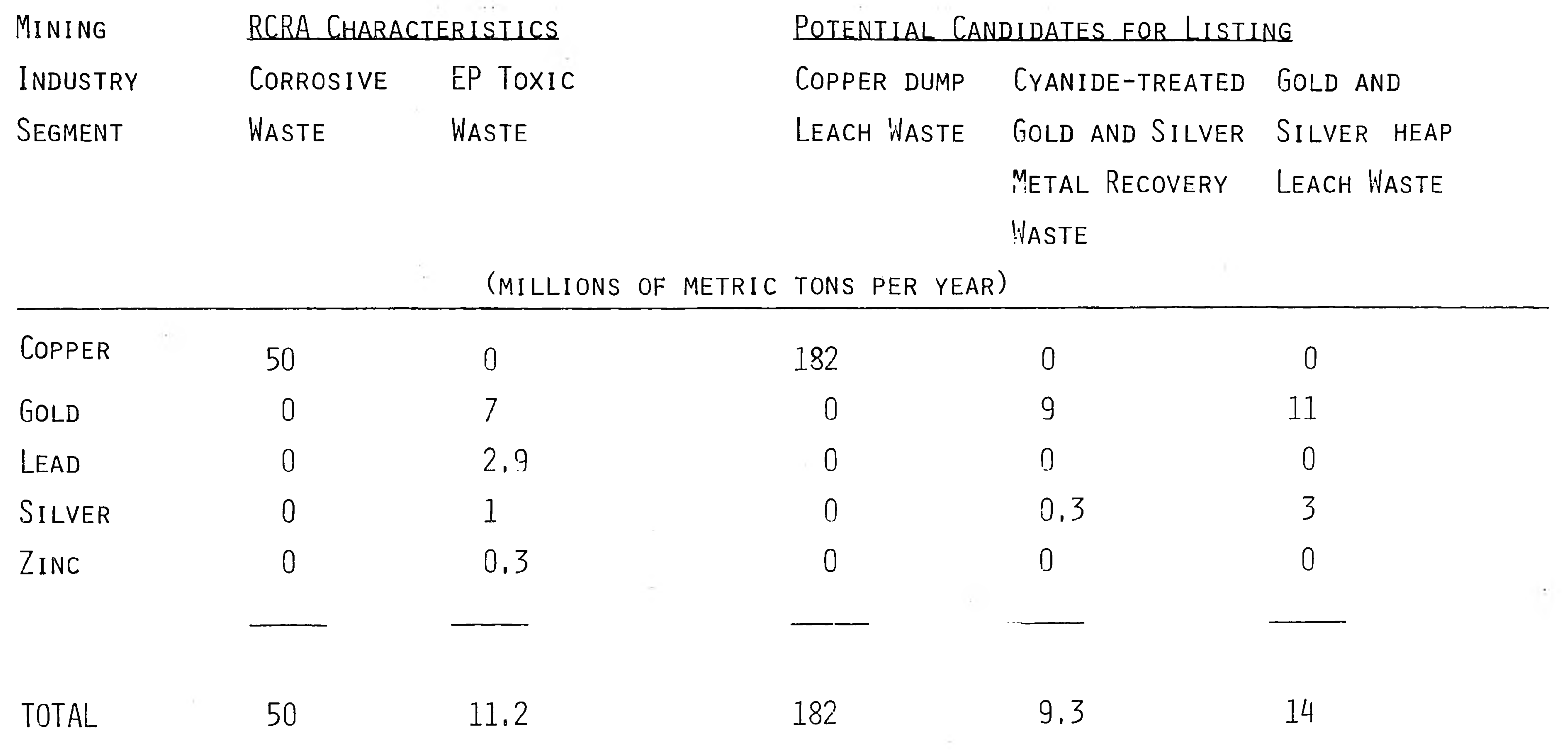

Source: Epa Mine Waste Report, Table 4-18, 
Numbers of Potential RCRA Mine Facilities and Quantities of Hazardous Waste in E?A Cost Study, Scenario A and $B$, by Mining Sector

NUMBER OF FACILITIES

Regulated/ PERcent TOTAL
ANNUAL WASTE GENERATION

(MILLIONS OF METRIC TONS/YEAR)

Regulated/ Percent

TOTAL

\section{SCEnARIO A}

\section{COPPER}

GOLD

SILVER

LEAD

ZINC

TOTALS
$6 / 22$

$75 / 100$

$12 / 50$

$$
3 / 7
$$

$3 / 12$

99/191
27

75

24

43

25

52
50/63?

13/65

$1 / 17$

$3 / 9$

$\frac{0.3 / 2.4}{67 / 725}$
7,9

19.6

5.7

33.3

$\frac{11.5}{9.3}$

Scenario B

COPPER

$21 / 22$

96

$276 / 532$

43.7

GOLD

$100 / 100$

100

24/65

36.6

SILVER

$25 / 50$

LEAD

$$
3 / 7
$$

ZINC

TOTALS

50

43
4/17

$3 / 9$

$\frac{0.3 / 2.4}{307 / 725}$
22.3

33.3

25

80
11.5

42.3

Source: EPA Mine Waste Report, Table 5-3, 
each of the two waste groups it is evident that the types of regulatory controls affect the total cost of compliance dramatically. Increasing the kinds of wastes regulated produces an even more dramatic effect on the costs of compliance. See Table 4. The copper industry would be the most affected of all the metal mining segments "because of the extremely large quantities of waste and the relatively high proportion of total waste that is of potential concern, particularly in the dump leaching and milling operations." 12 Total costs for different metal sectors are shown in Taule 5:

The EPA study also considered the effect of compliance costs on the operating costs for five metal segments. Under the highest-cost scenario, the incremental compliance costs would average about 20 percent of current operating costs for the lead segment on the low end, to 120 percent of the current operating costs for the copper segment on the high end.13 On the other hand, assuming the minimum regulatory controls are applied to the larger waste group, compliance costs average from about one to five percent of facility operating costs. See Table 6 . Because of the variation among individual mine sites, the EPA report also presents information showing the range of compliance cost effects on individual facilities for the two scenarios. Under the high-cost scenario the annualized costs of compliance vary from a low of $\$ 600,000$ for a typical silver mining facility, to a high of $\$ 35$ million per year for a typical copper mining facility. For the highest-cost copper mining 
Potential Total Cost For Metal Mining Industrya

Under Various RCRA Regulatory Scenarios

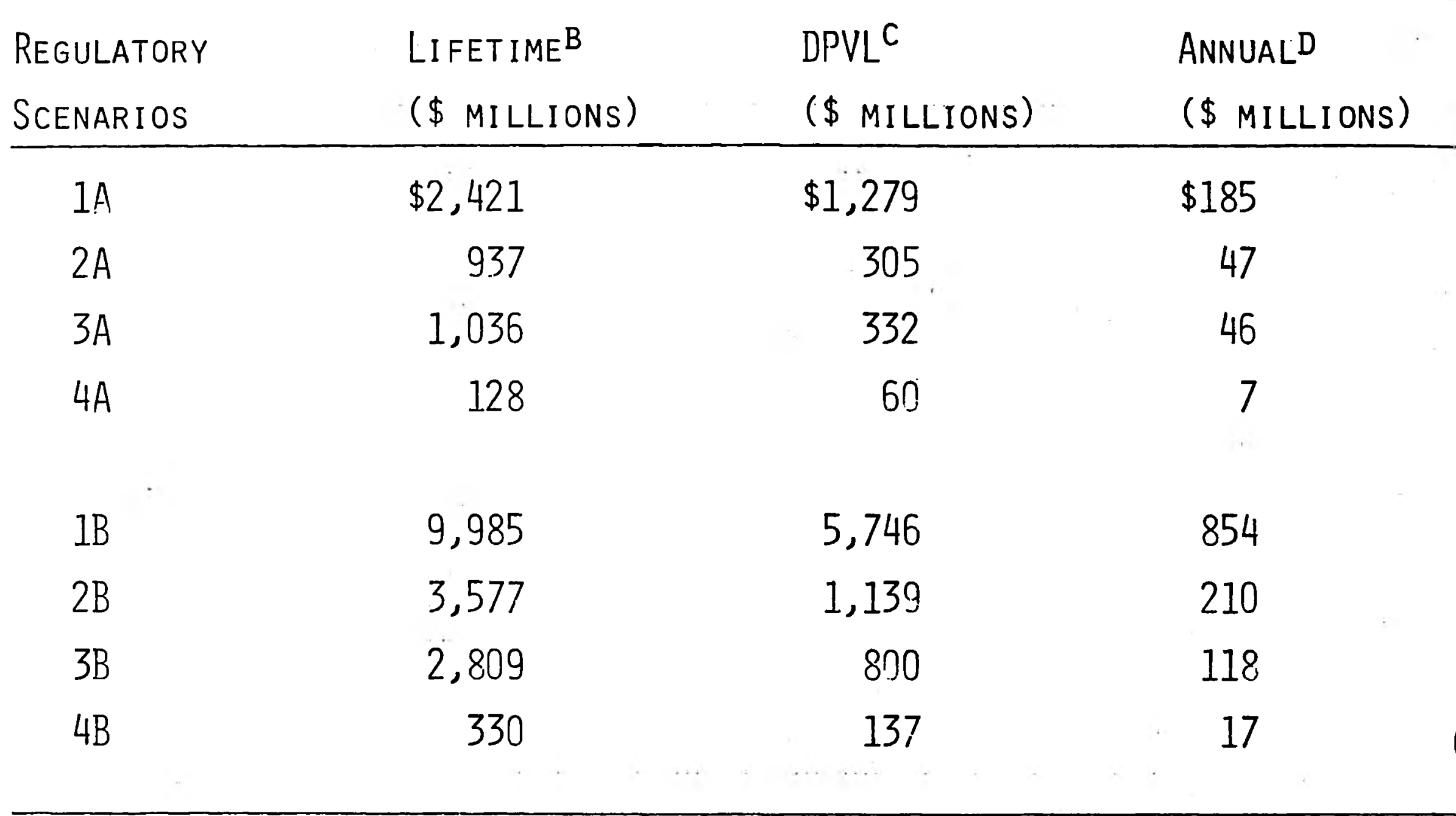

A INDUSTRY SEgMENTS INCLUDE: COPPER, LEAD, ZINC, GOLD, AND SILVER, B LifETIME COSTS (1985 DOLLARS), NOT DISCOUNTED, INCLUDING: CLOSURE AND 30 YEARS POST-CLOSURE COSTS FOR EXISTING WASTES; OPENING AND MANAGING A NEW WASTE MANAGEMENT FACILITY FOR 15-YEAR FUTURE OPERATIONS; CLOSURE AT END OF 15TH YEAR; POST-CLOSURE MANAGEMENT FOR 30 YEARS,

C Discounted Present Value of Lifetime Costs, As Listed in note (B), REAL DisCOUNT RATE OF 9,0 PERCENT,

D Lifetime Costs AnNualized OVER 15-year future Mine PRODUCTION PERIOD USING A REAL DISCOUNT RATE OF 9,0 PERCENT.

Source: epa Mine Waste Report, table 5-4, 
Potential Total Costs ${ }^{A}$ For Selected Metal Mining Sectors Under Various RCRA REgulatory ScEnarios

SUBTITLE $C$

$1 \mathrm{~A}$
IAILORED Standards

$2 \mathrm{~A}$

$2 B$

\section{SECTOR}

IB

ANNUALLZED COSTS ( $\$$ MILLION/YEAR) ${ }^{B}$

COPPER

GOLD

SILVER

LEAD

ZINC

TOTALS

$\$ 740$

75

16

19

4

4

19

$\$ 185$

$\$ 14$

17

4

9

3

$\$ 47$

$\$ 150$

37

11

9

3

A LifETIME COST (1985 DOLLARS), NOT DISCOUNTED, INCLUDING: CLOSURE AND 30 YEARS POST-CLOSURE COSTS FOR EXISTING WASTES; OPENING AND MANAGING A NEW WASTE MANAGEMENT FACILITY FOR 15-YEAR FUTURE OPERATIONS; CLOSURE AT END OF 15TH YEAR; POST-CLOSURE MANAGEMENT FOR 30 YEARS,

LifETIME COSTS ANNUALIZED OVER 15-yeAR FUTURE MINE PRODUCTION PERIOD, USING A REAL DISCOUNT RATE OF $9,0 \%$,

Source: Epa Mine Waste Report, Table 5-5. 
Potential Incremental RCRA Compliance Costs

Relative to Facility Production Costs

COST PER Unit OF PRODUCTA

(Dollars per metric ton) Percent of Direct Product Cost ${ }^{A}$

Average For

Average For

Affected High-Cost Affected High-Cost

Facilities Facility Facilities Facility

COPPER

GOLD

SILVER

LEAD

?INC

LOW-COST SCENARIO

\section{(4B)}

$\begin{array}{rrrr}\$ 17.6 & \$ 44.1 & 1.7 \% & 4 \% \\ 5,625.5 & 29,465.9 & 1.1 \% & 6 \% \\ 267.9 & 1,071.5 & 2.5 \% & 10 \% \\ 4.5 & 15.4 & 1.9 \% & 5 \% \\ 28.7 & 57.3 & 5.2 \% & 10 \%\end{array}$

HIGH-COST SCENARIO (IP)

COPPER

$$
\$ 1,212,5
$$

$\$ 3,417,1$

1?. $\%$

$340 \%$

GOLD

$117,867,6$

$267,881,0$

$23 \%$

$54 \%$

Silver

$4,286.1$

$16,608,5$

$40 \%$

$150 \%$

LEAD

60.6

253.5

$21 \%$

$88 \%$

ZINC

209.4

319.7

$30 \%$

$58 \%$

A DiRECT COSTS OF MINE PRODUCT ARE BASED ON SECTOR AVERAGES OF CURRENT CASH Operating COStS for facilities, as estimated by Charles River ASSOCIATES FOR EPA, COSTS DO NOT INCLUDE FACILITY-LEVEL CAPITAL INVESTMENT, DEPRECIATION, INTEREST EXPENSE, OR CORPORATE OVERHEAD.

Source: EPA Mine Waste Report, Table 5-7, 
facility, the annualized cost is estimated at \$190 million.14 The EPA report offers three "principal findings" regarding costs. First, the compliance costs associated with imposing regulations under RCRA would be substantial. Under the lowest possible cost scenario, the annual compliance costs for the metal mining industry would be $\$ 7$ million. The highest-cost scenario skyrockets that figure to $\$ 854$ million per year.15 Second, as these figures suggest, the costs vary markedly among the different regulatory scenarios. Third, the additional cost incurred by broadening the group of wastes regulated is substantial, at least two to three times as costly for the same regulatory measures, and the increase becomes more substantial as the degree of control is expanded.

THE REGULATORY SCHEME FOR MINING WASTES

Waste materials from mining are subjected to an array of regulatory controls.16 Regulation of new wastes is the focus of the Resource Conservation and Recovery Act (RCRA), enacted by Congress in 1976 and substantially amended in 1984.17 The Comprehensive Environmental Response, Compensation, and Liability Act of 1980 (CERCLA) 18 establishes a program addressing problems associated with existing waste disposal sites. The extent to which these two federal statutes apply to the metals mining industry has yet to be finally determined. In this section the general framework of these statutes is presented. Provisions directly affecting the mining industry are discussed in more 
detail.

Resources Conservation and Recovery Act

In 1976 Congress, having addressed the problems of air and water pollution, turned its attention to the land. By limiting the release of certain pollutants into the air and water, Congress had, of course, encouraged their disposal on the ground. With RCRA, Congress sought to "close the circle." The management of solid waste materials is handled in one part of the statute. A separate section addresses the management of hazardous wastes.

The solid waste management program is primarily intended to encourage better methods of solid waste disposal. EPA will provide technical and financial assistance to the states which establish acceptable programs. EPA has established "criteria" and "guidelines" which set out the manner in which solid wastes should be disposed. The applicability of this part of RCRA to mining was considered in the 1982 case of Chemical Manufacturers Association v. Environmental Protection Agency. 19 The District of Columbia Circuit Court noted that RCRA defines "solid waste" as including "discarded material... resulting from... mining...operations."20 It went on to uphold EPA's action which included mining waste in its criteria for controlling areas designated as "open dumps." Since such open dumps are prohibited under the EPA criteria, mine and mill sites must comply with practices required of sanitary landfills. However, several types of mining and milling wastes are 
exempted from regulation under the solid waste program. Of major importance, an exclusion is provided for "overburden resulting from mining operations intended for return to the mine site."21 Also excluded are operations subject to the hazardous waste regulation portion of RCRA and point source discharges subject to a permit under the Clean Water Act. 22

Hazardous waste regulation under RCRA is a mandatory program, reflecting the special concern of Congress with such materials. Hazardous waste is defined in RCRA as waste which because of its quantity, concentration or physical, chemical or infectious characteristics may (a) cause or significantly contribute to an increase in mortality or an increase in serious irreversible, or incapacitating reversible illness; or (b) pose a substantial present or potential hazard to human health or the environment when improperly treated, stored, transported, or disposed of, or otherwise managed. 23

The system of control established by RCRA for such waste often is referred to as "cradle to grave" because all hazardous wastes must be carefully managed throughout their life cycle.

Under RCRA, EPA is to identify and list hazardous wastes to be controlled. EPA must establish regulations governing the manner in which generators and transporters are to handle and track such wastes. Facilities for the treatment, storage, or disposal of hazardous waste are subjected to comprehensive performance standards. Controls are implemented by a permit system administered either by the states or by EPA. Hazardous wastes can be handled only at facilities operating under a RCRA permit. 
At this point RCRA's hazardous waste provisions do not apply to most mining wastes because of the temporary exclusion authorized by Congress in 1980 (the Bevill Amendment).24 This exclusion was enacted in response to EPA regulations implementing the hazardous waste provisions of RCRA which, although specifically excluding "overburden resulting from mining operations and intended for return to the mine site," would have included any wastes from mining determined to be ignitable, corrosive, reactive, or EP toxic. The 1980 Amendments prohibited EPA from regulating solid waste from the "extraction, beneficiation, and processing of ores and minerals, including phosphate rock and overburden from the mining of uranium ore" under the hazardous waste provisions of RCRA until at least six months after it completes two studies required by the 1976 and 1980 Acts.

Section 8002 (f) of the 1976 Act directed EPA to conduct a study of the "adverse effects of solid wastes from active and abandoned surface and underground mines on the environment, ...." The study was to consider the effects of such wastes on humans, water, air, health, welfare, and natural resources. It was also to consider the adequacy of practices currently employed by the mining industry to prevent or mitigate adverse effects in the disposal of such wastes. Alternative disposal methods and the cost of these methods also were to be considered. No completion date was established for this study.

The 1980 Act included a new provision (Section $8002(p)$ ) requiring a "detailed and comprehensive study on the adverse 
effects on human health and the environment, if any, of the disposal and utilization of solid waste from the extraction, beneficiation, and processing of ores and minerals,..." This study was to be done "in conjunction with" the subsection ( $f$ ) study. Specific items to be analyzed include: (1) the sources and volumes of such materials generated per year; (2) the present disposal and utilization practices; (3) potential danger, if any, to human health and the environment from the disposal and reuse of such materials; (4) documented cases in which danger to human health or the environment has been proved; (5) alternatives to current disposal methods; (6) the cost of such alternatives; (7) the impact of those alternatives on the use of phosphate rock and uranium ore, and other natural resources; and (8) the current and potential utilization of such materials. EPA submitted its report to Congress concerning "Wastes from the Extraction and Beneficiation of Metallic Ores, Phosphate Rock, Asbestos, Overburden from Uranium Mining, and Oil Shale" in December 1985. The findings and recommendations of this report will be discussed below.

In late 1980 EPA published an interim rule interpreting the scope of the exclusion as encompassing solid waste from the exploration, mining, milling, smelting, and refining of ores and minerals but as not applying to other wastes "such as spent solvents, pesticide wastes, and discarded commercial chemical products, that are not uniquely associated with these mining and allied processing operations." 25 Thus, mining is currently 
subject to RCRA hazardous waste regulation for what are termed "non-indigenous" or non-unique wastes which meet the hazardous waste criteria.

In 1984 Congress enacted major revisions to RCRA known as the Hazardous and Solid Waste Amendments of 1984.26 Section 3004 (x) provides that if mining wastes do become subject to hazardous waste regulation, EPA is authorized to modify a number of provisions relating to disposal practices

to take into account the special characteristics of such wastes, the practical difficulties associated with implementation of such requirements, and site-specific characteristics, including but not limited to the climate, geology, hydrology and soil chemistry at the site, so long as such modified requirements assure protection of human health and the environment. 27

By way of explanation the Conference Report accompanying the legislation states:

This Amendment recognizes that even if some of the special study wastes [which include mining wastes] are determined to be hazardous it may not be necessary or appropriate because of their special characteristics and other factors, to subject such wastes to the same requirements that are applicable to other hazardous wastes, and that protection of human health and the environment does not necessarily imply the uniform application of requirements developed for disposal of other hazardous wastes. 28

In October 1985 EPA issued a proposed rulemaking that would redefine the scope of the mining waste exclusion. 29 with respect to processing wastes, EPA proposes to exclude only certain large-volume processing wastes "such as slag from primary metal smelters and elemental phosphorous plants, red and brown 
muds from bauxite refineries, and phosphogypsum from phosphoric acid plants."30 These wastes would be further studied to determine if regulation is needed. All other processing wastes determined to be hazardous would be brought under full RCRA regulation.

To summarize RCRA's effect on the metals mining industry, mining waste falls within the statutory definition of solid waste. A mine or mill not meeting EPA-established criteria will be classified as an open dump and must be closed. Mining overburden is specifically excluded from regulation under this program.

Of greater potential significance to the mining industry is the hazardous waste program under RCRA. IF EPA determines that certain mining wastes with hazardous characteristics should be regulated, it will establish a program involving controls on the handling and disposal of such materials. Congress has demonstrated a recognition of the special problems involved in establishing such controls by requiring extensive studies and authorizing more flexible regulatory procedures. With respect to processing waste, EPA has already indicated its intention to institute regulation. EPA's decision regarding other mining wastes is expected by June 30, 1986 . 
Comprehensive Environmental Response Compensation, and Liability ACt

The Comprehensive Environmental Response, Compensation, and Liability Act of 1980 (CERCLA) 31 expands the scope of hazardous waste regulation in several respects. In large part it is concerned with the problem of releases of hazardous substances from abandoned disposal sites such as occurred at Love Canal. It requires all such sites to be reported. These sites are then to be evaluated to determine those requiring remedial action. A National Priority List of sites is to be established. Emergency response as well as abatement authority is provided to deal with actual or threatened releases of hazardous substances. Liability for the costs of a remedial action, an emergency response, or damage to natural resources is extended to any owner or operator of a facility from which there is a release or threatened release, prior owners and operators, persons arranging for the disposal of the substance, or persons transporting the substance. A fund of money is established (Superfund) from a tax on oil and certain chemicals to be used in the cleanup of hazardous sites.

An analysis of CERCLA's relation to mining begins with an examination of the substances subject to its provisions. CERCLA is concerned primarily with "hazardous substances." These are defined by reference to hazardous designations under other laws including the Clean Air Act, the Clean Water Act, the Toxic Substances Control Act, and RCRA. 32 In reference to RCRA, the definition states: "but not including any waste the regulation of 
which under [RCRA] has been suspended by Act of Congress."

The Eagle-Picher case 33 involved the question whether mining wastes can be considered hazardous substances under CERCLA. The Circuit Court noted that Congress had temporarily excluded mining waste from regulation under RCRA, but, nevertheless, concluded that a hazardous substance may be governed by CERCLA if it qualifies under any of the referenced statutes. The Court pointed out that,

[a]t the conclusion of [the definition section], a general exception from the definition of "hazardous substance" is carved out for petroleum and natural gas products. Had Congress intended to create a similarly broad exception for mining wastes and fly ash, the Legislature readily could have placed that exception alongside the petroleum and natural gas exceptions. 34

To the argument that this interpretation renders the exclusion language meaningless since virtually all mining wastes contain at least trace elements of substances identified as hazardous under other statutes, the Court responded that there was nothing in either the legislative or administrative record establishing this fact.

Moreover, the Circuit Court went on to note that mining wastes would qualify as either a pollutant or a contaminant, and thus be subject to certain of CERCLA's provisions. Under Section 104, releases of "any pollutant or contaminant which may present an imminent and substantial danger to the public health or welfare are subject to federal remedial action. This section includes a definition of "pollutant or contaminant" that 
emphasizes effects on human health. 35 Once again there is a specific exclusion for petroleum products. Consequently, releases of pollutants or contaminants from mining wastes presenting an imminent and substantial danger to the public health or welfare are within the reach of CERCLA.

The petitioners in Eagle-Picher were objecting to the inclusion of a number of mining and milling sites on the National Priority List. 36 This list includes those sites determined to be most in need of remedial action to prevent releases endangering the public health or welfare. In a separate but related decision, the Federal Appeals Court had considered the methodology used by EPA in determining which sites to list. 37 The mining industry had objected to the use of a modeling device known as the Hazardous Ranking System (HRS) because it was intended to evaluate chemical waste sites rather than mining sites, and thus failed to adequately consider the low concentration of hazardous substances in mining wastes. 38 The Court concluded that EPA's approach to listing sites, including its use of the HRS model, was a reasonable interpretation of its responsibilities under CERCLA.

Releases of hazardous substances into the environment from mining sites must be reported to a federal information center (the National Response Center). EPA has established a list of hazardous substances and defined quantities which, if released, must be reported. It is the responsibility of the site owner to clean up the release. CERCLA authorizes the federal government 
to respond if necessary. 39 The National Contingency Plan sets out the general approach to be taken in addressing emergency responses as well as long-term cleanup efforts. EPA is authorized to seek court-ordered abatement relief in event of an "imminent and substantial endangerment to the public health or welfare or the environment because of an actual or threatened release of a hazardous substance from a facility."40

The liability issue under CERCLA has been a major point of contention. The statute itself does not expressly establish any standard. However, the courts have uniformly agreed that Congress intended to impose a "strict liability" standard--that is, one in which the individual is held responsible for harm irrespective of whether he acted reasonably. Section 107 of CERCLA identifies four classes of persons who may be held liable for release of hazardous substances: (1) owners or operators of a facility from which the hazardous substance was released; persons who owned or operated the facility at the time of the hazardous substances were disposed of; (3) persons who arranged for the transportation, treatment, or disposal of the hazardous substance; and (4) persons transporting the hazardous substance. Any or all of these persons may be held liable for any response costs incurred by either the state or federal government. Except in cases involving willful negligence, the responsible party is liable for cleanup costs and damages up to a limit of $\$ 50$ million. In situations involving multiple parties, the courts generally have been willing to permit application of a "joint and 
several" liability standard under which an action may be taken against any one of the parties for all the costs involved.4l

Section 107 also authorizes either the federal government or the states to seek recovery of damages for "injury to, destruction of, or loss of natural resources,...." Any damages recovered are to be used to "restore, rehabilitate, or acquire the equivalent of such natural resources..." Natural resources are defined as "land, fish, wildlife, biota, air, water, ground water, drinking water supplies, and other such resources belonging to, managed by, held in trust by, appertaining to, or otherwise controlled by the United States..., any State or local government, or any foreign government."42 A substantial number of suits have been filed under this provision, including six filed by the state of Colorado involving mining and milling sites. In December 1985 the Department of the Interior issued a proposed rulemaking regarding procedures for assessing natural resources damages as required under section 301(c). Because of the potential significance of these natural resource damage cases to the mining industry, this part of CERCLA will be discussed at greater length below.

In summary, CERCLA seeks the identification and cleanup of sites containing hazardous substances the possible release of which threatens public health and welfare. Mining and milling sites are subject to the provisions of CERCLA. Strict liability for costs resulting from releases of hazardous substances from such sites may apply to a broad class of people associated with 
such sites. A number of mining and milling sites have been placed on the National Priority List. States such as Colorado also have filed suits seeking damages for injury to natural resources caused by releases from mining and milling sites. The significance of CERCLA to the metallic mining industry is evident.

\section{DISCUSSION OF SELECTED ISSUES}

The surge of concern about hazardous wastes in recent years appears likely to have a major impact on the mining industry. The mining process generates enormous quantities of waste. In the past this waste often was not well-managed. Management practices today are much improved, in substantial part because of the various federal and state regulatory controls. Nevertheless, the hazardous characteristics of certain mining-related wastes appear likely to lead EPA to develop some kind of comprehensive regulatory program. Of many possible issues, two are discussed here: assessment of damages to natural resources and likely EPA regulation of mining wastes. Damages to Natural Resources

There are a large number of lawsuits pending under the provision of CERCLA concerned with damage to natural resources. In December 1985 the Interior Department issued its proposed guidelines for assessing the cost of such damages. 43 The proposed process calls for (first) documenting the injury, (second) measuring the effects of the injury, and (third) 
determining the damages to be claimed. Injury to resources is defined, where possible, with reference to established EPA standards under legislation such as the Clean Air Act, the Clean Water Act, and the Safe Drinking water Act. Damage is to be measured based on the difference between the condition of the resource before the release and its condition afterward. Eight alternative economic methodologies are presented as potentially usable for determining the damage costs. 44

Assessment of such damages resulting from mining activities presents several problems. The release causing the damage must have existed after passage of CERCLA in 1980. In the miningrelated situations the effects on natural resources are likely to have accumulated over a number of years. Damages in historic mining districts may easily go back more than 100 years. In such instances, the baseline condition is obviously uncertain.

Such areas often have had a large number of mining activities historically. In most situations there will be no way to determine which activities have actually caused any particular damage. For example, one case in Colorado involving damage to natural resources caused by mine drainage through a tunnel system into the Arkansas River may involve as many as 500 parties with ownership and other interests in the tunnel system. 45 Moreover, in some cases the current owners of the mining properties may not have been the ones involved in the activities causing the damage. The larger quantities of mining waste constitute another problem. To restore the natural resources at these old mine 
sites it will be necessary to engage in massive movement of old tailings. Removal of contaminated subsurface materials may also be necessary. Reestablishment of vegetation in these areas is difficult because of climate and lack of topsoil. The remedial activities proposed by the state of Colorado for the Eagle mine involve a ten-year plan for removal of old materials. It's not clear where those materials would be taken.

The potential massive liability associated with old mining sites has sharply curtailed interest in obtaining exploration and development rights by new parties. Consequently these historic mining areas are effectively off limits for new exploration activity.

The state of Colorado has sponsored a study of the costs of the environmental damages associated with the Eagle mine. Three different approaches were explored.46 First, a property value study in the area of the Eagle mine was undertaken which showed substantially lower property values in the area compared to comparable properties in other areas. Second, a survey was undertaken of current recreation in the area to determine how much additional use would be made of the area if it were restored. The additional days of use were valued using Forest Service user day values. Third, a survey of the "existence" values or nonuser values was undertaken on a statewide basis. A contingent valuation methodology was employed. The results of these analyses indicate that the value of restoring the Eagle mine site (and, by implication, the other mining sites) is 
extremely high.

It may be expected that litigation in this area will move ahead more rapidly now that the general procedures for assessing damages has been announced. Certainly the process will be clarified and improved as it is applied. At this point it seems safe to assume that the transaction costs in seeking the damages are likely to represent a substantial portion of any money actually recovered for use in restoring or replacing the damaged resource.

Mining Waste Regulation

The EPA report indicates primary concern with mining wastes exhibiting the characteristics of corrosivity or EP toxicity established as hazardous under RCRA. In all likelihood regulatory controls under RCRA will be proposed for such wastes. Other wastes of concern, such as dump leach wastes and wastes containing cyanide, may also be subjected to regulation, but perhaps not until there has been further study.

Exposure to these hazardous wastes can result from transport through the air, the surface water, or the ground water. Documented instances of such damage were found in twenty cases and generally involved degradation of surface water ecosystems. Efforts to determine if ground water contamination was occurring were inconclusive. Considering the thousands of mine sites and the billions of tons of wastes, it seems somewhat surprising that so little apparent damage could be demonstrated. Moreover, these instances of damage appear to be associated with old sites and 
are the result of practices no longer followed.

The EPA report includes five regulatory controls in each of its scenarios: 1) permitting; 2) surface water run-on and run-off diversion/collection ditches (mine waste only); 3) ground water monitoring wells and testing; 4) leachate collection ditches; and 5) post-closure inspection, drainage maintenance, and ground water monitoring. 47 Possible additional controls include direct treatment of wastes to remove substances of concern, liners for all new waste areas, capping of sites at closure, and security fences around sites.

Assuming that, initially at least, EPA chooses to regulate only the mining wastes with RCRA characteristics, the annual cost to the metal mining industry could range from $\$ 7$ million to $\$ 185$ million, depending on the controls imposed. If metal processing wastes also are regulated, an additional $\$ 20$ million per year in compliance costs must be added.48 Given the current depressed state of the metals industry in the U.S., such additional costs would be significant.

Presumably EPA has learned enough about the nature of mining-related wastes and other special factors associated with the industry so that its regulations will be reflective of these factors. Certainly Congress, in requiring the two special studies of the wastes from mining, has indicated its concern with this problem. 
The legal controls attaching to hazardous mining wastes are reflective of the priority that has been given in the U.S. to protecting human health and environmental values. Under CERCLA, liability for damages to natural resources is being placed on persons irrespective of their actual responsibility for those damages. Furthermore the specter of liability for any costs resulting from a release of hazardous substances extends over anyone holding an interest in a mining property on which hazardous substances exist. Almost certainly this possible liability has chilled interest in becoming involved with such properties for exploration or development purposes. It seems doubtful if Congress, in reacting to a Love Canal incident, had in mind such a result.

Regulatory controls on at least certain kinds of newly generated mining wastes seem likely, even though the EPA report does not make an especially strong case for their need. The case for regulation appears to rest on the hazardous characteristics of certain wastes and the concern that if sufficient concentrations of such substances migrate off-site, damage could result. At this point, there appears to be no evidence of any threats to human health associated with mining wastes. The main possibility appears to be contamination of ground water aquifers being used as a source of drinking water.

Nevertheless, the current level of concern about hazardous wastes is substantial. Given this climate, it is likely that the 
regulatory agency will choose to initiate controls. The depressed condition of the domestic mining industry suggests that these controls should be imposed with care. Selective, specially designed regulations would be preferable to imposition of blanket controls aimed at different situations. Incremental phasing of the required controls would also be desirable.

Environmental regulation in the U.S. is a curious process. Congress establishes a general framework that is typically rather vague, leaving the real work of implementation up to a federal agency such as the EPA. EPA then spends millions of dollars hiring outside contractors to do the studies it needs to develop regulations. At the same time, the industry is spending similar sums of money hiring other contractors to review the work of the EPA contractors. Some adjustments are made and then the regulations are made final. Industry may then litigate to challenge certain aspects of the regulation. Much of the expense involved in this adversarial process is wasted. It is unfortunate that matters like control of hazardous waste generated by an industry cannot be dealt with in a more cooperative, problem-solving mode. As attested to by the now ten years of studies and counter-studies, proposed regulations, and litigation, that has not been our approach in deciding how to regulate mining wastes. 
1. The findings from studies of these sites are presented in "remedial investigation" reports prepared by the CERCLA Litigation Section of the Colorado office of the Attorney General.

2. U.S. Environmental Protection Agency, Report to Congress: Wastes from the Extraction and Beneficiation of Metallic Ores, Phosphate Rock, Asbestos, Overburden from Uranium Mining, and oil Shale (December 1985), p. 2-19, Table 2-8 (hereinafter EPA Mine Waste Report).

3. Id. at 2-3, Table 2-I and 2-20, Table 2-9. Because of the severe slump in the mining industry, this figure is down considerably from the 1.5 billion metric tons of waste generated in 1980 .

4. Id. at 2-22, Table 2-11. The report also notes that mine water may be another waste product.

5. Id., p. 4-2.

6. Id., p. 4-49.

7. Id., p. 4-71.

8. Id., p. 4-69.

9. Id., pp. 4-50 to 4-68.

10. To analyze compliance costs EPA established two different waste groups for control and four different levels of regulatory controls--thus a total of eight possible regulatory scenarios. The more narrow waste group included wastes meeting the EPA tests for EP toxicity and corrosivity, as well as gold mine tailing wastes from cyanide-process metal recovery operations. The larger waste group also includes waste from gold and silver heap leach operations, waste with high acid formulas potential, and copper dump leach liquids. EPA Mine Waste Report, p. 5-3. The regulatory standards included a minimum set of controls involving permitting, surface water run-on and run-off diversion/collection ditches, ground water monitoring wells and testing, leachate collection ditches, and post-closure inspection, drainage maintenance, and ground water monitoring. The maximum-control scenario (scenario l) also requires a security fence, capping of both existing and new waste sites at closure, corrective action via interceptor wells for existing waste amounts (assuming 10 percent require this), and liners for all new waste piles, leaching areas, and tailing ponds. In addition to the common minimum requirements, scenario 2 added the substitution of waste treatment processes where feasible. It also 
assumes that all sites would need interceptor wells (rather than the initial assumption that only 10 percent would need them.) Scenario 3 is similar to 2 except that cyanide is not removed from gold and silver tailings and sulfides are not removed from copper mill tailings. Scenario 4 is the least-cost approach involving only those requirements listed originally. EPA Waste Report, pp. 5-4 and 5-5.

11. Id., p. 5-15, Table 5-4. The high cost assumptions place about 80 percent of the industry under regulation involving about 40 percent of all the wastes generated. Maximum regulatory control would include a security fence, capping of all waste sites at closure, action to clean up contaminated ground water, and liners for all new waste piles. Id., p. 5-4.

12. Id., pp. 5-18 to 5-19.

13. Id., p. 5-21, Table 5-7. The operating costs do not include facility-level capital investment, depreciation, interest expense, or corporate overhead.

14. Id., p. 5-19, Table 5-6.

15. Id., p. 5-15, Table 5-4.

16. For example, the Clean Water Act regulates point source discharges of water. The Surface Mining Control and Reclamation Act directly controls the disposal of solid wastes resulting from surface coal mines. Mining activities on public lands are subject to regulation by the Forest Service and the Bureau of Land Management. A survey of such programs is provided in E. McGrath \& K. Kulasza, Solid and Hazardous Waste Disposal in the Minerals Industries, Rocky Mt. Min. Law Inst. Annual Proceedings, Vol. 27, pp. 65-126 (Matthew Bender, 1982).

17. Pub. L. No. 94-580, 90 Stat. 2795 and Pub. L. No. Stat., , codified at

18. Pub. L. No. 96-510, 94 stat. 2767, codified at 42 U.S.C. $\$ \$ 9601-9657$ (__ $)$.

19. 673 F.2d 507 (D.C. Cir. 1982).

20. Id. at 511, citing 42 U.S.C. $\$ 6903$ (27).

21. 40 C.F.R. $\$ 257.1(\mathrm{C})(2)$ 。

22. 40 C.F.R. $\$ \$ 257.1(\mathrm{c})(6)$ and (9).

23. 42 U.S.C. $\$ 6903(5)$. 
24. The exclusion included in the Solid Waste Disposal Act Amendments of 1980 often is referred to as the Bevill Amendment. Pub. L. No. 96-482, 94 Stat. 2334 (1980), codified at 42 U.S.C. $\$$ $6921(\mathrm{~b})(3)(\mathrm{A})(\mathrm{ii})(\ldots$

25. 45 Fed. Reg. 76619, Nov. 19, 1980.

26. Pub. L. $98-616$, Stat.

27. Specifically, modifications are permitted in the provisions concerning (1) liquids in landfills; (2) prohibitions on land disposal; (3) solvents and dioxins; (4) disposal into deep injection wells; (5) additional land disposal prohibits determinations; (6) minimum technological requirements; (7) continuing releases at permitted facilities; and (8) interim status surface impoundments.

28. H.R. Report 98-1133, pp. 93-94, Oct. 3, 1984.

29. 50 Fed. Reg. 40292 , Oct. 2, 1985.

30. EPA Mine Waste Report at $1-8$.

31. Pub. L. 96-570, 94 Stat. 2767 (1980).

32. Section $101(14), 42$ U.S.C.

33. Eagle-Picher Industries, Inc. v. United States Environmental Protection Agency, 759 F.2d 922 (D.C. Dir. 1985).

34. Id. at 927 .

35. The full text is as follows:

(2) For the purposes of this section, "pollutant or contaminant" shall include, but not be limited to, any element, substance, compound, or mixture, including diseasecausing agents, which after release into the environment and upon exposure, ingestion, inhalation, or assimilation into any organism, either directly from the environment or indirectly by ingestion through food chains, will or may reasonably be anticipated to cause death, disease, behavioral abnormalities, cancer, genetic mutation, physiological malfunctions (including malfunctions in reproduction) or physical deformations, in such organisms or their offspring. The term does not include petroleum, including crude oil and any fraction thereof which is not otherwise specifically listed or designated 
as hazardous substances under section

$101(4)(A)$ through (F) of this title, nor does

it include natural gas, liquefied gas, or

synthetic gas of pipeline quality (or

mixtures of natural gas and such synthetic gas).

36. The original list included 17 mining or mining-related sites out of a total of 418. Another 5 mining sites have been proposed for addition to the 1ist. ALM 2nd, \$171.04(2)(c).

37. Eagle-Picher Industries, Inc. v. United States Environmental Protection Agency, 759 F.2d 905 (D.C. Cir. 1985).

38. The HRS "score," calculated by use of this model, results from an analysis three categories of factors "designed to encompass most aspects of the likelihood of exposure to a hazardous substance through release and the magnitude or degree of harm from such exposure." These categories are (1) the existence or likelihood of a release; (2) the characteristics of the hazardous substances that have been or may be released, and (3) the population or sensitive environment that is threatened. 47 Fed. Reg. at 31,187 (date).

39. Possible response actions include removal of the released substance and remedial actions such as relocation of people living nearby. In general federal actions are likely to be limited to emergency situations in which no other good options are available and to coordinated cleanup programs involving state and private participation.

40. Section 106, 42 U.S.C. $\$ 9606$ (a)

41. See the discussion in ALM 2nd, $\$ 171.05(4)(c)$, p. 171-29.

42. Section $101(16), 42$ U.S.C.

43. 50 Fed. Reg. 52126 et seg. (December 20, 1985).

44. These range from assessing the cost of returning the resources to their pre-damage condition, to determining their market value, to imputing value based on other factors.

45. State of Colorado v. Asarco, Inc., F. Supp. (D. Colo. 1985) [May 13]. In this case the state sued Asarco which has in turn filed third party complaints seeking contribution from 15 named third-party defendants who are said to own mining claims through which the Yak Tunnel and its laterals traverse. Asarco estimates that there are 200 to 500 potential third-party defendant class members. 
46. Telephone interview with william Schulze, Department of Economics, University of Colorado, Boulder (May 23, 1986).

47. EPA Mine Waste Report, pp. 5-4 \& 5-5.

48. 50 Fed. Reg. 40292, 40299 (Oct. 2, 1985). 